\title{
Differential effect of some arbuscular mycorrhizal fungi on growth of Piper longum L. (Piperaceae)
}

\author{
P. Gogoi and R. K. Singh \\ Department of Botany, Rajiv Gandhi University, Rono Hills, Itanagar-791112, Arunachal Pradesh, India \\ purnimagogoi17@rediffmail.com, rajivsinghau@rediffmail.com
}

\begin{abstract}
The potential for arbuscular mycorrhizal fungi (AMF) to influence the host species depends on their affinities and effects. Twenty three different AMF strains from nearby localities were evaluated for their symbiotic response with Piper longum (long pepper). Saplings were raised in $10 \mathrm{~cm}$ thick sand-soil mix inoculated with isolates of different AM fungi. Almost all the studied AMF strains showed increase in plant growth, biomass and nutrient content (N\&P) over the control, while retarded growth response was observed with the inoculation of 6 different AMF species. Considering the shoot length, total biomass, nutrient content, chlorophyll content and root infection, pre-inoculation with 6 AMF species viz; Glomus fasciculatum, G. versiforme, G. clarum, Glomus sp. 2, G. mosseae and G. etunicatum appeared to be the most promising AM fungi for inoculating this medicinal plant.
\end{abstract}

Keywords: Arbuscular mycorrhizal fungi, Piper longum, Biomass, Glomus spp., Root infection,

Introduction

Piper longum L (Hindi: Pipli, Pipal, Piper; Assamese: Pipoli, Family: Piperaceae) is the most commonly known species of long pepper. It forms an important component in ayurvedic principles/preparations such as 'Trikadu' (dry ginger, black pepper \& long pepper) and 'Panchakolam'. $P$. longum is described in the ayurvedic and unani systems of medicine as a valuable drug used for treatment of various kinds of ailments (Viswanathan, 1995; Sivarajan \& Balachandran, 1996). Due to increasing demand at national and global level with the trend of $16.3 \%$ increase per annum have added value to this plant species, concurrently entangled in prioritized list by national medicinal plant board of India. It is cultivated in Arunachal Pradesh as well as it grows in wild condition in different parts of the State in India (Misra \& Dutta, 2003). It is being collected from forest and sold to local and outside agencies. The rising demands have otherwise dramatically declined the stock in wild thereby necessitates the provocation of large-scale cultivation. Arunachal Pradesh renders wide scope for large scale cultivation of $P$. longum due to its congenial climate and vast land resource.

AMF are soil fungi colonizing most of the plant roots and forming an association called endomycorrhiza. More than $90 \%$ of plants and $80 \%$ of plant families in all terrestrial environments form the association (Harley \& Harley, 1987) with these obligate fungi belonging to the group Glomeromycota (Schubler et al., 2001). These fungi are known to improve the nutritional status of the host, particularly that of phosphorous and thereby enhance their growth, development and yield (Bagyaraj \& Varma, 1995; Bagyaraj, 2007). Different AMF species induce differential growth responses in terms of biomass production and clonal growth patterns of co-existing plant species (Heijden et al., 1998). AMF are not host specific and show extremely wide host range but their affinity to the host is always preferential (Rogers et al., 1994), thus suggesting the need for selecting efficient $A M$ fungi for a particular host (Abbott \& Robson, 1982; Gracy \& Bagyaraj, 2005). Hence in the present investigation it was envisaged to screen and select efficient AM strains for this particular host in order to harness the maximum benefit from the fungus in the nursery.

\section{Materials and methods}

A green house experiment was conducted to observe the different effect of the indigenous AM fungi on growth, nutrient and chlorophyll content of medicinal plant Piper longum. The soil used in this study was collected from the botanical garden, Rajiv Gandhi University from a depth of $0-15 \mathrm{~cm}$ and has been classified as sandy loam. The soil had a pH of $5.5 \pm 0.02$ and it contained $3.98 \pm 0.65$ ( $\mu \mathrm{gg}$ $\left.{ }^{1}\right)$ available phosphorous. The experimental design was completely randomized block design with 10 replicates for each treatment. Treatments consisted of saplings without AMF (control) and pre-infected saplings with any one of the 23 AMF species. For each AMF species, inoculation beds were prepared separately in green house. The beds were filled up with sand-soil mix and the rooting medium was inoculated into the bed with culture of individual AMF species by uniformly distributing its propagules i.e. large inoculum of endogone sporocarps and mycelium. Soilbased $A M$ inoculum at the rate of $40 \mathrm{gkg}^{-1}$ soil was taken out from a pure culture pot of AMF for preparing a bed. Beds were $10 \mathrm{~cm}$ thick where inoculum were placed by preparing a layer $\left(1 / 4^{\text {th }}\right.$ of sand-soil mixture) so that growing root of cuttings can pass through this inoculum layer, then the remaining soil was topped over the inoculum layer, levelled and pressed down. Large numbers of piper cuttings of uniform size were planted temporarily in each bed.

AMF used for inoculation were Acaulospora delicata, A. rugosa, Gigaspora candida, Glomus aggregatum, G. albidum, G. aurantium, G. claroideum, G. clarum, G. coronatum, G. etunicatum, G. fasciculatum,
Research article

CIndian Society for Education and Environment (iSee)
"VAM aided herbal cultivation" http://www.indjst.org
Gogoi \& Singh Indian J.Sci.Technol. 
G. geosporum, G. glomerulatum, G. hoi, $G$. intraradices, $G$. macrocarpum, $G$. mosseae, G. occultum, G. versiforme, $G$. xanthium, Glomus sp. 2, Glomus sp. 4, and Glomus sp. 5. An inoculated or uninoculated sapling along with rhizospheric soil, without disturbing the rooting zone was taken from respective nursery bed and planted by making a core in the centre of pots containing $200 \mathrm{~g}$ autoclaved sandsoil mixture. The AMF spores were isolated using wet sieving and decanting method (Gerdemann \& Nicolson, 1963) from the trap culture of soil samples collected from seven different field sites of Arunachal Pradesh, viz, Open forest (Rajiv Gandhi university), Jhum field (Midpu village), Forest area (Karsingsa), Settled agriculture (Doimukh village), Home garden (Rajiv Gandhi University), Pine forest (Ziro town), and Tea garden (Harmutty), an adjoining area of Assam.

The experimental pots were maintained in the green house at a temperature of 22 $\pm 1^{\circ} \mathrm{C}$, with $12 \mathrm{~h}$ fluorescent illumination with 8000 Ix light intensity and water was supplied daily to maintain the soil moisture level close to field capacity. Inorganic nutrients were thoroughly incorporated to the soil at the rate $\left(\mathrm{mgkg}^{-1}\right)$ at potting stage. $\mathrm{N}$ and $\mathrm{P}$ in the form of urea and single super phosphate and $\mathrm{K}$ as murate of potash was used in the ratio of 66:110:30 respectively.

Harvesting was carried out for $90 \mathrm{~d}$ after planting (DAP) and further destructive and non-destructive growth measurements were taken. The plant parameters like plant height (measured from soil surface to the growing tip of the plant), were recorded at $90 \mathrm{~d}$ interval after planting (DAP). Shoot and root dry weights were determined after drying the plant samples at $60^{\circ} \mathrm{C}$ to a constant weight in a hot air oven. The phosphorus content of the shoot and root was determined by the method of Hanson (1950). For determination of total nitrogen, microkjeldhal method of Bremner \& Mulvaney (1982) was followed. Chlorophyll content of leaf was measured by using the method of Arnon (1949).

\section{Statistical analysis}

The data obtained were statistically analyzed using Analysis of Variance (ANOVA) and the means were separated by Duncan's multiple range test (DMRT) $(\mathrm{P}<$ 0.05) using computer statistics programme SPSS (2000) Version 10.1.0.

\section{Results}

The effect of inoculation of different AM fungi on growth performance of $P$. longum plants was evaluated in
Vol. 4 No. 2 (Feb 2011)

ISSN: 0974- 6846
Table 1. Effect of AM fungal inoculation on shoot length, shoot fresh weight \& shoot dry weight of $P$. longum saplings.

\begin{tabular}{|c|c|c|c|}
\hline AMF species & $\mathrm{SL}(\mathrm{cm})$ & SFV (g & $\operatorname{SDW}(\mathrm{g})$ \\
\hline Control & $07.3 \pm 0.519^{\mathrm{a}}$ & $0.26 \pm 0.023^{\mathrm{a}}$ & $0.07 \pm 0.008^{\mathrm{a}}$ \\
\hline Acaulospora delicata & $12.2 \pm 0.771^{\mathrm{b}}$ & $0.66 \pm 0.019^{\mathrm{ad}}$ & $0.15 \pm 0.003^{\text {cdef }}$ \\
\hline A. rugosa & $08.5 \pm 0.645^{\mathrm{a}}$ & $0.34 \pm 0.027^{\mathrm{ab}}$ & $0.08 \pm 0.002^{\mathrm{a}}$ \\
\hline Gigaspora candida & $17.5 \pm 0.925^{\mathrm{efg}}$ & $0.78 \pm 0.113^{\mathrm{bcd}}$ & $0.17 \pm 0.005^{\text {cdef }}$ \\
\hline Glomus aggregatum & $08.3 \pm 0.829^{\mathrm{a}}$ & $0.34 \pm 0.041^{\mathrm{ab}}$ & $0.07 \pm 0.009^{\mathrm{a}}$ \\
\hline G. albidum & $17.8 \pm 0.984^{\mathrm{efg}}$ & $0.84 \pm 0.040^{\text {cd }}$ & $0.24 \pm 0.005^{9}$ \\
\hline G. aurantium & $08.3 \pm 0.667^{a}$ & $0.34 \pm 0.034^{\mathrm{ab}}$ & $0.07 \pm 0.007^{\mathrm{a}}$ \\
\hline G. claroideum & $12.2 \pm 0.359^{\circ}$ & $0.88 \pm 0.038^{\mathrm{cd}}$ & $0.21 \pm 0.035^{19}$ \\
\hline G. clarum & $16.0 \pm 0.651^{\text {cdet }}$ & $2.09 \pm 0.098^{n 1}$ & $0.47 \pm 0.020^{K}$ \\
\hline G. coronatum & $14.0 \pm 0.463^{c}$ & $0.59 \pm 0.028^{\mathrm{abcd}}$ & $0.13 \pm 0.004^{\mathrm{DCd}}$ \\
\hline G. etunicatum & $16.5 \pm 0.838^{\mathrm{de}}$ & $1.72 \pm 0.257^{g n}$ & $0.36 \pm 0.029^{\prime}$ \\
\hline G. fasciculatum & $31.0 \pm 1.083^{J}$ & $2.77 \pm 0.307^{J}$ & $0.54 \pm 0.024$ \\
\hline G. geosporum & $19.3 \pm 0.718^{g h}$ & $1.34 \pm 0.205^{\mathrm{ef}}$ & $0.264 \pm 0.018^{g}$ \\
\hline G. glomerulatum & $11.5 \pm 0.696^{b}$ & $0.63 \pm 0.039^{\mathrm{abc}}$ & $0.19 \pm 0.003^{\mathrm{e}}$ \\
\hline G. hoi & $05.0 \pm 0.493^{\mathrm{a}}$ & $0.23 \pm 0.015^{a}$ & $0.06 \pm 0.003^{\mathrm{a}}$ \\
\hline G. intraradices & $10.2 \pm 0.704^{b}$ & $0.35 \pm 0.020^{\mathrm{ab}}$ & $0.09 \pm 0.001^{\mathrm{ab}}$ \\
\hline G. macrocarpuı & $12.5 \pm 0.907^{\circ}$ & $0.41 \pm 0.030^{\mathrm{ab}}$ & $0.11 \pm 0.013^{\mathrm{abc}}$ \\
\hline G. mosseae & $20.7 \pm 0.707^{n 1}$ & $1.82 \pm 0.308^{9}$ & $0.37 \pm 0.038^{J}$ \\
\hline G. occultum & $10.5 \pm 0.538^{\mathrm{b}}$ & $0.54 \pm 0.033^{\mathrm{abc}}$ & $0.14 \pm 0.007^{\mathrm{abc}}$ \\
\hline G. versiforme & $22.8 \pm 0.704^{\prime}$ & $1.90 \pm 0.282^{\prime}$ & $0.38 \pm 0.053^{J}$ \\
\hline G. xanthium & $14.2 \pm 0.772^{\mathrm{c}}$ & $1.02 \pm 0.112^{\mathrm{de}}$ & $0.29 \pm 0.007^{n}$ \\
\hline Glomus sp. 2 & $21.0 \pm 0.820^{h}$ & $1.78 \pm 0.318^{\dagger}$ & $0.35 \pm 0.025^{11}$ \\
\hline Glomus sp. 4 & $15.2 \pm 0.773^{\text {cde }}$ & $1.41 \pm 0.110^{\mathrm{etg}}$ & $0.30 \pm 0.072^{\text {hi }}$ \\
\hline Glomus sp. 5 & $15.0 \pm 0.454^{\text {cd }}$ & $0.89 \pm 0.037^{c}$ & $0.24 \pm 0.007^{9}$ \\
\hline
\end{tabular}
within same column for each parameter are not significantly different at $p \leq 0.05$ with respect to species main effect. Decrease values underlined with same letter within same column for each parameter are not significantly different at $p \leq 0.05$ levels by Duncan's multiple range test with respect to species main effect.

pot conditions. The results obtained after completion of the experiment showed a positive effect of AM inoculation on different growth parameters viz. root and shoot length, fresh and dry weight of root and shoot, total biomass, chlorophyll content and percent root colonization of $P$. longum plants.

\section{Effects on shoot length}

With the exception of 4 AM species (i.e. Acaulospora rugosa, Glomus aggregatum, G. aurantium \& G. hol), inoculation with all other 19 AMF species showed a significant increase in shoot length in comparison to uninoculated control plants. The highest shoot length was observed with the inoculation of $G$. fasciculatum, which was followed by other 5 inoculants viz. Glomus versiforme, Glomus sp. 2, G. mosseae, G. geosporum and $G$. etunicatum while the lowest being observed in $G$ intraradices inoculated plants. Among the 23 tested AMF species, inoculation with 3 species viz. Acaulospora rugosa, $G$. aggregatum and $G$. aurantium had more shoot length than the non-mycorrhizal plants but the increase was non-significant. On the other hand, plants inoculated with $G$. hoi showed less shoot length than the control plants (Table 1). 
Indian Journal of Science and Technology

Effects on shoot fresh weight \& shoot dry weight

Out of 23 AM species tested for efficiency, 9 species failed to show a significant effect in increasing both the shoot fresh weight and shoot dry weight over the un-inoculated control plants. Again G. hoi inoculated plants showed decrease in both shoot fresh weight and dry weight in comparison to the uninoculated control plants. The maximum percent increment of shoot weight and shoot biomass production was about 10 fold \& 7 fold, respectively in plants inoculated with $G$. fasciculatum. This AMF species was followed by other 5 mycorrhizal species, viz. (G. clarum, G. versiforme, G. mosseae, Glomus sp. 2 \& $G$. etunicatum) in respect to their shoot fresh weight and shoot biomass increment capacity (Table 1 ).

Effects on root fresh weight, root dry weight \& total biomass

Only 3 out of 23 species (Glomus sp. 2, G. fasciculatum \& G. clarum) showed a significant increase over un-inoculated control in respect to root fresh weight and root dry weight as well as total biomass. Significantly highest total biomass $(0.84 \mathrm{~g})$ production was observed in $G$. fasciculatum inoculated plants when compared to un-inoculated control plants. Ten AMF species (Gigaspora candida, Glomus albidum, G. etunicatum, G. geosporum, G. glomerulatum, $G$. mosseae G. xanthium, G. versiforme, Glomus sp. 4 \& Glomus sp. 5) could not significantly increase the root fresh weight and root dry weight of the $P$. longum over un-inoculated control plant but they showed a significant increase in total biomass in comparison to control plants due to significantly high increase in shoot biomass. Among these above mentioned species, Inoculation with 4 AMF species ( $A$. delicata, G. claroideum, G. coronatum \& G. occultum) showed a non-significant effect on biomass production whereas 6 AMF species ( $A$. rugosa, G. aggregatum, G. aurantium, G. hoi, G. macrocarpum \& $G$. intraradices) caused a depression to the biomass in comparison to control plants (Table 2).

\section{Effects on chlorophyll content of P. longum}

A significant increase in chlorophyll content over the control was observed in plants inoculated with $G$. fasciculatum, G. clarum, G. versiforme and G. etunicatum only. Nine AMF inoculants showed non-significant increase whereas inoculation with remaining $10 \mathrm{AMF}$ species showed rather a decrease in chlorophyll content in comparison to control plants.
Vol. 4 No. 2 (Feb 2011)

ISSN: 0974- 6846

Table 2. Effect of AM fungal inoculation on root fresh weight, root dry weight \& total biomass.

\begin{tabular}{|c|c|c|c|}
\hline AMF species & RFW (g) & RDW (g) & Total biomass $(\mathrm{g})$ \\
\hline Control & $0.62 \pm 0.033^{\mathrm{a}}$ & $0.17 \pm 0.018^{\mathrm{a}}$ & $0.23 \pm 0.019$ \\
\hline Acaulospora delicata & $0.46 \pm 0.035^{\mathrm{a}}$ & $0.12 \pm 0.010^{\text {bet }}$ & $0.27 \pm 0.010^{\mathrm{a}}$ \\
\hline A. rugosa & $0.26 \pm 0.027^{b}$ & $0.08 \pm 0.004^{\top}$ & $0.16 \pm 0.005^{b}$ \\
\hline Gigaspora candida & $0.56 \pm 0.031^{\mathrm{a}}$ & $0.15 \pm 0.031^{\mathrm{abc}}$ & $0.32 \pm 0.030^{\mathrm{cd}}$ \\
\hline Glomus aggregatum & $0.36 \pm 0.028^{b}$ & $0.08 \pm 0.005$ & $0.15 \pm 0.011^{b}$ \\
\hline G. albidum & $0.59 \pm 0.036^{\mathrm{a}}$ & $0.14 \pm 0.028^{\mathrm{abccd}}$ & \begin{tabular}{|l}
$0.37 \pm 0.033^{\text {cdetg }}$ \\
\end{tabular} \\
\hline G. aurantium & $0.36 \pm 0.042^{b}$ & $0.09 \pm 0.007^{\mathrm{et}}$ & $0.16 \pm 0.004^{\mathrm{b}}$ \\
\hline G. claroideum & $\underline{0.31 \pm 0.046^{b}}$ & $0.09 \pm 0.001^{\mathrm{et}}$ & $0.30 \pm 0.034^{\mathrm{abcd}}$ \\
\hline G. clarum & $1.03 \pm 0.048^{\mathrm{C}}$ & $0.24 \pm 0.018^{c}$ & $0.71 \pm 0.031^{\top}$ \\
\hline G. coronatum & $0.38 \pm 0.028^{\mathrm{b}}$ & $0.10 \pm 0.002^{\mathrm{def}}$ & $0.23 \pm 0.004^{\mathrm{a}}$ \\
\hline G. etunicatum & $0.76 \pm 0.041^{\mathrm{ab}}$ & $0.17 \pm 0.013^{\mathrm{a}}$ & $0.53 \pm 0.033^{\text {nin }}$ \\
\hline G. fasciculatum & $1.46 \pm 0.130^{\circ}$ & $0.30 \pm 0.019^{\mathrm{d}}$ & $0.84 \pm 0.041^{\mathrm{K}}$ \\
\hline G. geosporum & $0.80 \pm 0.033^{b}$ & $0.11 \pm 0.010^{\text {cde }}$ & $0.38 \pm 0.020^{\text {detg }}$ \\
\hline G. glomerulatum & $0.48 \pm 0.046^{\mathrm{ab}}$ & $0.13 \pm 0.013^{\text {abcde }}$ & $0.31 \pm 0.015^{\mathrm{ab}}$ \\
\hline G. hoi & $0.33 \pm 0.036^{b}$ & $0.08 \pm 0.002^{1}$ & $0.14 \pm 0.005^{b}$ \\
\hline G. intraradices & $0.45 \pm 0.030^{\mathrm{ab}}$ & $0.12 \pm 0.003^{\text {bcdf }}$ & $0.21 \pm 0.002^{b}$ \\
\hline G. macrocarpum & $0.34 \pm 0.040^{\text {ab }}$ & $0.09 \pm 0.007^{\dagger}$ & $0.21 \pm 0.014^{\mathrm{b}}$ \\
\hline G. mosseae & $0.66 \pm 0.033^{\mathrm{ab}}$ & $0.20 \pm 0.130^{\mathrm{abc}}$ & $0.57 \pm 0.039^{\prime}$ \\
\hline G. occultum & $0.57 \pm 0.043^{\mathrm{a}}$ & $\underline{0.15 \pm 0.015^{\mathrm{ab}}}$ & $0.29 \pm 0.021^{\mathrm{abc}}$ \\
\hline G. versiformae & $0.77 \pm 0.031^{\mathrm{ab}}$ & $0.18 \pm 0.017^{\mathrm{ab}}$ & $0.55 \pm 0.044^{\prime}$ \\
\hline G. xanthium & $0.57 \pm 0.029^{\mathrm{a}}$ & $0.15 \pm 0.027^{\mathrm{abc}}$ & $0.45 \pm 0.025^{g n}$ \\
\hline Glomus sp. 2 & $1.12 \pm 0.197^{\mathrm{C}}$ & $0.29 \pm 0.014^{\mathrm{d}}$ & $0.64 \pm 0.023^{J}$ \\
\hline Glomus sp. 4 & $0.55 \pm 0.030^{\mathrm{a}}$ & $0.15 \pm 0.017^{\mathrm{abc}}$ & $0.44 \pm 0.082^{9}$ \\
\hline Glol & $.029^{\circ}$ & $16^{\mathrm{ab}}$ & 0.40 \\
\hline
\end{tabular}

$R L=$ Root length; $R F W=$ Root fresh weight; $R D W=$ Root dry weight.

Values are means of 10 replicates \pm standard error. Values with the same letter Whespect to species main effect. Decrease values underlined with same letter thin same column for each parameter are not significantly different at $p \leq 0.05$

levels by Duncan's multiple range test with respect to species main effect.

\section{Effect on nutrient uptake}

Out of 23 species, merely 15 species showed significant increase of nitrogen over the un-inoculated plants (Table 3 ). The maximum nitrogen concentration was recorded in plants inoculated with $G$. clarum which was followed by other 4 AMF species viz. G. occultum, $G$. versiforme, G. etunicatum and $G$. mosseae respectively. The shoot nitrogen content of plant was not affected by inoculation with the remaining species. Similarly, the shoot phosphorous content was significantly higher in plants inoculated with 5 AMF species only viz. G. clarum, G. etunicatum, G. mosseae, G. versiforme, Glomus sp. 2 compared to that of controls, whereas the inoculation of plant with the remaining species showed non-significant increase of phosphorous over the un-inoculated control.

\section{Percent infection of different $A M F$ in $P$. longum plant}

Out of 23 AMF species, 11 species produced $\geq 40 \%$ root infection in the root of $P$. longum (Fig.1). Inoculation with $G$. fasciculatum showed significantly highest infection (56\%) which was followed by Glomus sp. 4 (52\%), Glomus sp. 2 (50\%) and G. claroideum (50\%) (Fig.1). The Gigaspora species resulted into $>40 \%$ infection. It was also recorded that both Acaulospora species had $<35 \%$ infection whereas all Glomus species 
Vol. 4 No. 2 (Feb 2011)

ISSN: 0974- 6846
Table 3. Chlorophyll content, phosphorous \& nitrogen content of $P$. longum plant due to AMF inoculation.

\begin{tabular}{|c|c|c|c|}
\hline AMF species & $\begin{array}{c}\text { Chlorophyll } \\
\text { content }(\mathrm{mg} / \mathrm{g})\end{array}$ & $\mathrm{N}(\%)$ & $\mathrm{P}(\%)$ \\
\hline Control & $0.39 \pm 0.074^{\mathrm{a}}$ & $0.36 \pm 0.056^{a}$ & $0.08 \pm 0.019^{a}$ \\
\hline Acaulospora delicata & $0.37 \pm 0.069^{\mathrm{a}}$ & $0.46 \pm 0.034^{\mathrm{abcd}}$ & $0.09 \pm 0.011^{\mathrm{ab}}$ \\
\hline A. rugosa & $0.06 \pm 0.008^{b}$ & $0.48 \pm 0.035^{\mathrm{abcd}}$ & $0.09 \pm 0.021^{\mathrm{a}}$ \\
\hline Gigaspora candida & $0.23 \pm 0.032^{\mathrm{a}}$ & $0.48 \pm 0.062^{\mathrm{abcd}}$ & $0.11 \pm 0.012^{c}$ \\
\hline Glomus aggregatum & $0.35 \pm 0.085^{\mathrm{a}}$ & $0.50 \pm 0.034^{\text {cde }}$ & $0.11 \pm 0.006^{\mathrm{C}}$ \\
\hline G. albidum & $0.30 \pm 0.070^{\mathrm{a}}$ & $0.50 \pm 0.040^{\text {cae }}$ & $0.10 \pm 0.017^{\mathrm{DC}}$ \\
\hline G. aurantium & $0.05 \pm 0.015^{b}$ & $0.44 \pm 0.047^{\mathrm{abcd}}$ & $0.11 \pm 0.031^{\mathrm{C}}$ \\
\hline G. claroideum & $0.41 \pm 0.080^{\mathrm{a}}$ & $0.50 \pm 0.042^{\text {cde }}$ & $0.11 \pm 0.006^{\mathrm{C}}$ \\
\hline G. clarum & $1.16 \pm 0.262^{D}$ & $0.63 \pm 0.042^{\mathrm{rg}}$ & $0.13 \pm 0.012^{\mathrm{d}}$ \\
\hline G. coronatum & $0.52 \pm 0.035^{a}$ & $0.45 \pm 0.044^{\mathrm{abcd}}$ & $0.09 \pm 0.009^{\mathrm{ab}}$ \\
\hline G. etunicatum & $1.40 \pm 0.315^{c}$ & $0.61 \pm 0.049^{\mathrm{etg}}$ & $0.21 \pm 0.020^{\mathrm{e}}$ \\
\hline G. fasciculatum & $0.98 \pm 0.095^{b}$ & $0.52 \pm 0.043^{\mathrm{def}}$ & $0.09 \pm 0.020^{\mathrm{ab}}$ \\
\hline G. geosporum & $0.39 \pm 0.083^{\mathrm{a}}$ & $0.49 \pm 0.033^{\text {bcde }}$ & $0.09 \pm 0.017^{\mathrm{ab}}$ \\
\hline G. glomerulatum & $0.21 \pm 0.015^{a}$ & $0.38 \pm 0.035^{\mathrm{abc}}$ & $0.09 \pm 0.012^{\mathrm{ab}}$ \\
\hline G. hoi & $0.52 \pm 0.082^{\mathrm{a}}$ & $0.50 \pm 0.051^{\text {cde }}$ & $0.08 \pm 0.019^{\mathrm{a}}$ \\
\hline G. intraradices & $0.24 \pm 0.039^{a}$ & $0.51 \pm 0.045^{\text {det }}$ & $0.11 \pm 0.020^{C}$ \\
\hline G. macrocarpum & $0.15 \pm 0.021^{\mathrm{a}}$ & $0.39 \pm 0.046^{\mathrm{abcd}}$ & $0.10 \pm 0.020^{b}$ \\
\hline G. mosseae & $0.53 \pm 0.066^{\mathrm{a}}$ & $0.53 \pm 0.053^{\mathrm{der}}$ & $0.13 \pm 0.027^{\mathrm{d}}$ \\
\hline G. occultum & $0.29 \pm 0.039^{a}$ & $0.63 \pm 0.045^{\dagger}$ & $0.09 \pm 0.013^{\mathrm{ab}}$ \\
\hline G. versiforme & $0.89 \pm 0.155^{b}$ & $0.59 \pm 0.054^{\mathrm{eg}}$ & $0.20 \pm 0.012^{\mathrm{e}}$ \\
\hline G. xanthium & $0.55 \pm 0.088^{\mathrm{a}}$ & $0.50 \pm 0.048^{\text {cde }}$ & $0.09 \pm 0.016^{\mathrm{ab}}$ \\
\hline Glomus sp. 2 & $0.55 \pm 0.032^{\mathrm{a}}$ & $0.52 \pm 0.062^{\mathrm{det}}$ & $0.11 \pm 0.005^{c}$ \\
\hline Glomus sp. 4 & $0.44 \pm 0.053^{\mathrm{a}}$ & $0.51 \pm 0.041^{\text {det }}$ & $0.08 \pm 0.022^{\mathrm{a}}$ \\
\hline Glomus sp. 5 & $0.49 \pm 0.081^{\mathrm{a}}$ & $0.37 \pm 0.032^{\mathrm{ab}}$ & $0.09 \pm 0.015^{\mathrm{ab}}$ \\
\hline
\end{tabular}

Values are means of 10 replicates \pm standard error. Values with the same letter within same column for each parameter are not significantly different at $p \leq 0.05$ with respect to species main effect. Decrease values underlined with same letter within same column for each parameter are not significantly different at $p \leq 0.05$ levels by Duncan's multiple range test with respect to species main effect.

\section{Discussion}

Results of the experiments confirm various reports on enhanced plant growth due to $A M$ inoculation to medicinal plants (Earanna, 2001; Bobby \& Bagyaraj 2003; Nisha \& Rajeshkumar, 2010) and forest trees species (Vasanthakrishna et al., 1995; Rajan et al., 2000). Most of the AM fungi resulted in significant increase in plant height, root and shoot dry weight, plant biomass, chlorophyll and nutrient contents (N\&P) of $P$. longum. Specially, biomass accumulation by the seedlings was significantly promoted by 13 AMF species. In most cases, increase in shoot length and biomass was significant due to the inoculation of $G$. fasciculatum followed by other 5 inoculants viz, $G$. versiforme, Glomus sp. 2, G. mosseae, G. geosporum and $G$. etunicatum, respectively. It may possibly be due to the host preference of AM species as reported by many workers in some medicinal plant species like Phyllanthus amarus and Withania somnifera (Earanna, 2001) and Coleus forskohlii (Gracy \& Bagyaraj, 2005). It has been reported that species of AM fungi differ significantly in their ability to improve plant growth and other aspect of plant performance also (Liu \& Luo 1988; Liu, 1989). The concentrations of $N$ and $P$ in shoots were improved by all 20 three AMF species, though significant increase was excluding 3 viz. $G$. albidum, $G$. hoi and G. macrocarpum showed $>35 \%$ infection. A. rugosa treated plants had lowest $(24 \%)$ infection in the roots. observed with the inoculation of 4 AMF only viz, $G$. etunicatum. G. clarum, G. mosseae and G. versiforme.

Fig. 1. Percent root infection by AMF species in P. longum roots.

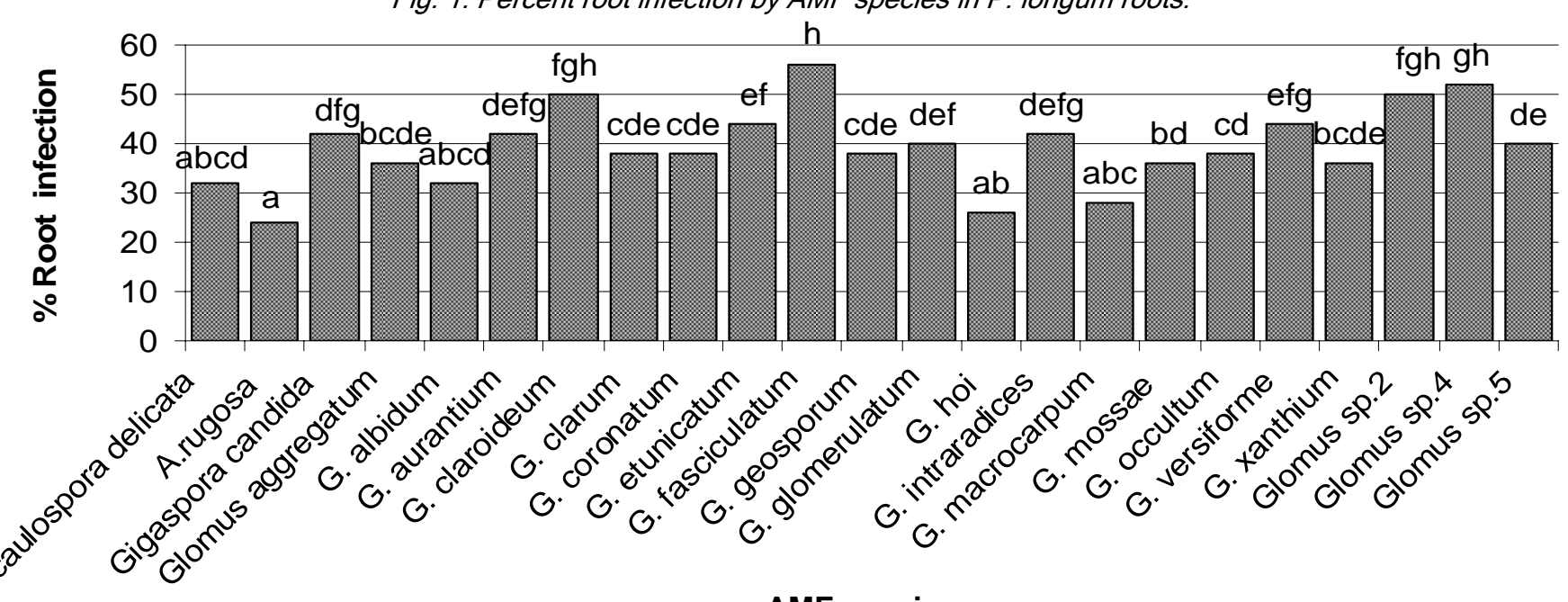

AMF species

Bar with the same letter are not significantly different at $p \leq 0.05$ levels by Duncan's multiple range test with respect to species main effect.

Research article

CIndian Society for Education and Environment (iSee)
"VAM aided herbal cultivation" http://www.indjst.org
Gogoi \& Singh Indian J.Sci.Technol. 
These results are consistent with the findings of Azcon et al. (1991) that the differences in functional compatibility, the ability of AMF to improve plant nutrition and growth existed among AMF even when the root colonization was found to be similar for $G$. clarum and $G$. coronatum and others. Mycorrhizal inoculation also increased phosphorous content of plants. Phosphorous being a constituent of phosphonucleotides which tend to increase cell division (Black, 1965) might increase the plant growth. The increased ' $P$ ' content may be attributed to increase in uptake of $\mathrm{P}$ facilitated due to $\mathrm{AM}$ colonization through various mechanisms. Hattingh et al. (1973) suggested that faster movement of $P$ into mycorrhizal hyphae and solubilization of soil $P$ could be some of the means for increasing $\mathrm{P}$ content in mycorrhizal plants. Faster movement of $P$ into the mycorrhizal hyphae is achieved due to increased affinity of $P$ ions and thereby decreasing the threshold concentration required for absorption of $P$. Further solubilization of soil $P$ is achieved by the release of organic acids and phosphates (Bolan, 1991). Increase in the N content in AM inoculated plants has been reported by many workers (Kessel et al., 1985). They described the increase in $N$ content to improved plant nutrition and not to the fungal activity. Thus, mycorrhiza may improve the $\mathrm{N}$ nutrient not as a result of extensive absorbing surfaces, but by some mechanism that accelerates other parts of $\mathrm{N}$ uptake processes (Megan et al., 1978). Increased chlorophyll accumulation was observed in all AM inoculated plants. Higher $\mathrm{P}$ levels in tissues as a result of root colonization by the AM can be expected to increase the chlorophyll content, as $P$ is one of the important components of chlorophyll. Increase in chlorophyll content due to AM symbiosis has been also reported by Adivappar (2001), Richmond \& Lang (1975) and Shivaputra et al. (2004).

The present study also supports the findings of Zhu et al. (2000) that certain AM fungi may be preferentially associated with particular plant species and helping the host plant to get a better nutrient status. It has been reported that even if AM fungi are considered to have a wide host range, there is some degree of ecological specificity between AM fungi and plants (Rosendahl et al., 1992). The efficiency of the fungus to increase plant growth in a phosphate-deficient soil depends on the ability to form extensive and well-distributed hyphae in soil to form extensive colonization in the root system and to absorb $P$ from soil. Hence, the need for selecting efficient AM fungi that can be used for inoculating different mycotrophic plants has been stressed by different workers (Abbott \& Robson 1982; Bagyaraj \& Varma 1995; Jeffries, 1987). The results also showed a negative growth response induced by $6 \mathrm{AM}$ species $(A$. rugosa, G. aggregatum, G. aurantium, G. hoi. $G$. intraradices \& $G$. macrocarpum) cogitating that the development of this mutual association relies on recognition between AMF species and the host plants. Wang et al. (2008) observed the similar response with the inoculation of $G$. versiforme in cucumber seedlings indicating that this species requires enough time for the proper establishment that results in the imbalance of the carbohydrate distribution between the shoots and the roots of the plants. It has been also found that AMF species are different in their carbon demands from the host plant (Saikkonen et al., 1999). They drain carbohydrates from host plants in demand for life at the cost of root biomass loss of host plants (Thomson et al., 1986; Fredeen \& Terry 1988). This finding of the present study is also consistent with the reports of Gaur \& Adholeya (2005) and Bethlenfalvay et al. (1982) that a negative growth response by the host or parasitism of the fungus might result from extensive intra-radical fungal growth in want of sufficient extra radical mycelium. A direct relationship between degree of plant growth stimulation or depression and degree of colonization has been reported by Clapperton \& Reid (1992) suggesting that the root-colonizing organisms are most likely to effect the changes to assimilate partitioning. Further, several workers have also suggested that lipids in hyphae and spores of AM fungi might cause a significant drain in the host carbohydrate supply thus resulting in negative growth response (Ho \& Trappe, 1973; Cox et al., 1975).

Growth depression in plants when colonized by AM fungi have been reported in many studies (Mosse, 1972; Sanders et al., 1977; Menge et al., 1978; O'Bannon et al., 1980; Azcon \& Ocampo, 1981; Buwalda \& Goh 1982; Schenck \& Smith 1982; Nuffelen \& Schenck, 1984). This negative effect has been attributed to the root system architecture (Baylis, 1970), high concentration of available inorganic nutrients (Buwalda \& Goh, 1982), or high inoculum density of AM fungi (Clapperton \& Reid, 1992). It must also be noted that AM fungi harbour some endo-symbiotic bacteria (Bianciotto et al., 1996) which may play a role causing these apparent growth depressions in plant. Schenck \& Smith (1982) found Gigaspora species as plant growth depressive however; in the present study $G$. candida significantly increased the biomass of $P$. longum. Growth depression in acid soils might also result from lack of activity of microorganisms that form mutualistic associations with the plants that form arbuscular mycorrhiza (Yost \& Fox, 1979; Abbott \& Robson, 1985). The AM fungal species causing growth depressions in the experiments with piper plants may represent fungal cheaters as they did not enhance the growth and mineral nutrition of the host plants. In the present study, only 6 AMF namely Glomus fasciculatum, G. versiforme, G. clarum, Glomus sp. 2, G. mosseae and G. etunicatum species tested were found to be the most excellent for endorsement of favourable growth, nutritional responses and economic yield in $P$. longum production under protected conditions.

\section{Acknowledgement}

The authors are thankful to the Department of Biotechnology, New Delhi for providing fund for this study 
and also the Department of Botany, Rajiv Gandhi University for providing the essential laboratory facilities to carry out the experiments.

\section{References}

1. Abbott LK and Robson AD (1982) The role of vesicular-arbuscular mycorrhizal fungi and selection of fungi for inoculation. Aust. J. Agric. Res. 33, 389-408.

2. Abbott LK and Robson AD (1985) The effect of soil pH on the formation of VA mycorrhizas by two species of Glomus. Aust. J. Agric. Res. 23, 253-261.

3. Adivappar N (2001) Effect of VAM fungi on growth, yield and drought tolerance of Pappaya. M.Sc. Thesis, Dharwad, India: University of Agricultural Science.

4. Arnon DI (1949) Copper enzymes in isolated chloroplasts and polyphenol oxidase in Beta vulgaris. Plant Physiol. 24,1-15.

5. Azcon R and Ocampo JA (1981) Factors affecting the vesicular-arbuscular infection and mycorrhizal dependency of thirteen wheat cultivars. New Phytol. 87, 677-685.

6. Azcon R, Rubio R and Barea JM (1991) Selective interactions between different species of mycorrhizal fungi and Rhizobium meliloti strains and their effects on growth, $\mathrm{N}_{2}$-fixation $(15 \mathrm{~N})$, and nutrition of Medicago sativa L. New Phytol. 117, 399-404.

7. Bagyaraj DJ (2007) Arbuscular mycorrhizal fungi and their role in Horticulture. In: Recent trends in horticultural biotechnology. Keshavchandran et al. (Eds.), pp:53-58.

8. Bagyaraj DJ and Varma A (1995) Interactions between arbuscular mycorrhizal fungi and plants: their importance in sustainable agriculture in arid and semiarid tropics. Adv. Microbial Ecol. 14, 119-142.

9. Baylis GTS (1970) Root hairs and phycomycetous mycorrhizas in phosphorous-deficient soil. Plant Soil. 33, 713.

10.Bethlenfalvay GJ, Brown MS and Pacovsky RS (1982) Relationships between host and endophyte development in mycorrhizal soyabeans. New Phytol. $90,537-543$.

11.Bianciotto V, Bandi C, Minerdi D, Sirom M, VolkerTichy H and Bonfante P (1996) An obligately endosymbiotic mycorrhizal fungus itself harbours obligately intracellular bacteria. Appl. Environ. Micro. 62, 3005-3010.

12. Black CA (1965) Methods of soil analysis. American Society Agronomy. Madison, WI, pp:1114-1132.

13. Bobby VU and Bagyaraj DJ (2003) Biological control of root rots of Coleus forskohlii Briq. using microbial inoculants. World J. Microbiol. Biotechnol. 19, 175185.

14.Bolan NS (1991) A critical review on the role of mycorrhizal fungi in the uptake of phosphorus by plants. Plant Soil. 134, 189-217.

15. Bremner JM and Mulvaney CS (1982) Nitrogen-total. In: Page AL (Eds) Methods of soil analysis. Part II.
American Society of Agronomy; Soil Science Society of America, Madison, Wisc.

16.Buwalda JG and Goh KM (1982) Host-fungus competition for $\mathrm{C}$ as a cause of growth depressions in vesicular-arbuscular mycorrhizal rye-grass. Soil Biol. Biochem. 14, 103-106.

17.Clapperton MJ and Reid DM (1992) A relationship between plant growth and increasing VA mycorrhizal inoculum density. New Phytol. 120, 227-234.

18.Cox G, Sanders FE, Tinker PB and Wild JA (1975) Ultrastructural evidence relating to host-endophyte transfer in a vesicular-arbuscular mycorrhiza. In: Sanders FE, Mosse B, Tinker PB (eds) Endomycorrhizas, London: Academic Press. pp: 29712.

19.Earanna N (2001) VA mycorrhizal association in medicinal plants of Southeastern dry zone of Karnataka and response of Phyllanthus amarus and Withania somnifera to inoculation with VAM fungi and plant growth promoting rhizomicroorganisms. Ph.D thesis. Submitted to University of Agricultural Sciences, Bangalore.

20. Fredeen AL and Terry N (1988) Influence of vescicular-arbuscular mycorrhizal infection and soil phosphorus levels on growth and carbon metabolism of soybean. Can. J. Bot. 66, 2311-2316.

21. Gaur A and Adholeya A (2005) Diverse response of 5 ornamental plant species to mixed indigenous and single isolate arbuscular-mycorrhizal inocula in marginal soil amended with organic matter. J. Plant. Nutr. 28,707-723.

22.Gerdemann JW and Nicolson TH (1963) Spores of mycorrhizal endogone species extracted from soil by wet sieving and decanting. Trans. Br. Mycol. Soc. 46, 235-244.

23.Gracy LS and Bagyaraj DJ (2005) Influence of different AM fungi on growth, nutrition and forskolin content of Coleus forskohlii. Mycol. Res. 109, 795798.

24. Hanson WC (1950) The photometric determination of phosphorous in fertilizers using the phosphovanadomolybdate complex. J. Sci. Food Agri. 1, 172-173.

25. Harley JL and Harley EL (1987) A check list of mycorrhiza in the British flora. Supplement to: The New Phytol. 105(2), Acad. Press London.

26. Hattingh MJ, Gray LE and Gerdemann JW (1973) Uptake and translocation of Phosphorous-32 labelled phosphate to onion roots by endomycorrhizal fungi. Soil Sci. 116, 383-387.

27. Heijden V MGA, Klironomos JN, Ursic M, Moutoglis $P$, Streitwolf-Engel R, Boller T, Wiemken A and Sanders IR (1998) Mycorrhizal fungal diversity determines plant biodiversity, ecosystem variability and productivity. Nature. 396, 69-72.

28. Ho I and Trappe JM (1973) Translocation of 14C from festuca plants to endomycorrhizal fungi. Nature New Biol. 244, 30-31.
Research article

CIndian Society for Education and Environment (iSee)
"VAM aided herbal cultivation" http://www.indjst.org
Gogoi \& Singh Indian J.Sci.Technol. 
29. Jeffries $P$ (1987) Use of mycorrhizae in agriculture, CRC. Crit. Rev. Biotechnol. 5, 319-357.

30.Kessel C, Paul WS and Heinz JH (1985) Enhance N transfer from a soybean to maize by vesiculararbuscular mycorrhizal fungi. Plant Physiol. 79, 562563.

31.Liu A, Hamel C, Hamilton RI, Ma BL and Smith DL (2000) Acquisition of $\mathrm{Cu}, \mathrm{Zn}, \mathrm{Mn}$ and $\mathrm{Fe}$ by mycorrhizal maize (Zea mays L.) grown in soil at different $\mathrm{P}$ and micronutrient levels. Mycorrhiza. 9, 331-336.

32.Liu RJ (1989) Effects of vesicular-arbuscular mycorrhizas and phosphorous on water status and growth of Malus hupehensis. J. Plant Nutr. 12, 9971019.

33.Liu RJ and Luo XS (1988) Effects of vesiculararbuscular mycorrhizas on the growth, mineral nutrition and water relations of cherry (Cerasus psedocerasus). J. Lai-Yang Agri. College. 5, 6-13.

34. Megan H, Lloyd WM and Patrick JB (1978) Mycorrhizal influence on the nutrition of Strawberries. J. Amer. Soc. Horticultural Sci. 103, 179-181.

35. Menge JA, Steirle D, Bagy Araj DJ, Johnson ELV and Leonard RT (1978) Phosphorus concentrations in plants responsible for inhibition of mycorrhizal infection. New Phytol.80, 575-578.

36. Misra MK and Dutta R (2003) Base line information on medicinal plants conservation and sustainable utilisation (Sponsored by UNDP/GEF, MoEF, Govt. of India \& Coordinated by foundation for revitalisation of local health traditions (FRLHT), Bangalore), Arunachal Pradesh.

37.Mosse B (1972) The influence of soil type and endogone strain on the growth of mycorrhizal plants grown in phosphate deficient soils. Rev. Ecol. Biol. Sol. 9, 529-537.

38.Nisha MC and Rajeshkumar S (2010) Effect of arbuscular mycorrhizal fungi on growth and nutrition of Wedilia chinensis (Osbeck) Merril.Indian J. Sci. Technol. 3(6), 676-678.

39. Nuffelen MV and Schenck NC (1984) Spore germination, penetration and root colonisation of six species of vesicular-arbuscular mycorrhizal fungi on soybean. Can. J. Bot. 62, 624-628.

40. O'Bannon JH, Evans DW and Peaden RN (1980) Alfalfa varietal response to seven isolates of VA mycorrhizal fungi. Can. J. Plant. Sci. 60, 859-863.

41.Rajan SK, Reddy BJD and Bagyaraj DJ (2000) Screening of arbuscular fungi for their symbiotic efficiency with Tectona grandis. Forest Ecol. Manage. 126, 91-95.

42.Richmond A and Lang A (1975) Effect of Kinetin on protein content and survival of detached Xantium leaves. Sci. 125, 650-651.

43. Rosendahl S, Rosendahl CN and Sochting U (1992) Distribution of VA mycorrhizal endophytes amongst plants from a Danish grassland community. Agric.
Ecosyst. Environ. 29, 329-335.

44. Saikkonen K, Ahonen-Jonnarth U, Markkola AM, Helander M, Tuomi J, Riotto M and Ranta H (1999) Defoliation and mycorrhizal symbiosis: A functional balance between carbon sources and below-ground sinks. Ecol. Lett. 2, 19-26.

45.Sanders FE, Tinker PB, Black RL and Palmerley SM (1977) The development of endomycorrhizal root system I. Spread of infection and growth promoting effects wit four species of vesicular arbuscular mycorrhizae. New Phytol. 78, 257-268.

46. Schenck NC and Smith GS (1982) Responses of six species of vesicular-arbuscular mycorrhizal fungi and their effects on soybean at four soil temperatures. New Phytol. 92, 193-201.

47. Schubler A, Schwarzott D and Walker C (2001) A new fungal phylum, the Glomeromycota: phylogeny and evolution. Mycol. Res. 105, 1413-1421.

48. Shivaputra SS, Patil CP, Swamy GSK and Patil PB (2004) Cumulative effect of VAM fungi and vermicompost on nitrogen, phosphorous, potassium and chlorophyll content of Papaya leaf. Mycorrhiza News. 16, 15-16.

49. Sivarajan VV, Balachandran I (1996) Ayurvedic drugs and their plant sources. Published by Mohan Primalini for Oxford \& IBH Publishing Company, PVT. LTD, New Delhi. pp: 374-376.

50.Subramanian KS, Charest C (1999) Acquisition of N by external hyphae of an arbuscular mycorrhizal fungus and its impact on physiological responses in maize under drought-stressed and well-watered conditions. Mycorrhiza. 9, 69-75

51. Thomson BD, Robson AD and Abbott LK (1986) Effects of phosphorous on the formation of mycorrhizas by Gigaspora calospora and Glomus fasciculatum in relation to root carbohydrates. New Phytol. 103, 751-765.

52. Vasanthakrishna $M$, Bagyaraj DJ and Nirmalnath JP (1995) Selection of efficient VA mycorrhizal fungi for Casuarina equisetifolia - Second screening. New Forests. 9, 157-162.

53.Viswanathan TV (1995) Medicinal and Aromatic Plants, In: Advances in Horticulture. Chadha KL \& Gupta Rajendra (Eds.), vol. 1, pp: 373-383.

54.Wang C, Li X, Zhou J, Wang G and Dong Y (2008) Effects of Arbuscular Mycorrhizal Fungi on Growth and Yield of Cucumber Plants. Commun. Soil Sci. Plant Analysis. 39, 499-509.

55. Yost RS and Fox RL (1979) Contribution of mycorrhizae to $\mathrm{P}$ nutrition of crops growing on an oxisol. Agron. J. 71, 903-908.

56.Zhu YG, Laidlaw AS, Christie $P$ and Hammond MER (2000) The specificity of arbuscular mycorrhizal fungi in perennial ryegrass-white clover pasture. Agric. Ecosyst. Environ. 77, 211-218.
Research article

COIndian Society for Education and Environment (iSee)
"VAM aided herbal cultivation" http://www.indjst.org
Gogoi \& Singh Indian J.Sci.Technol. 